\title{
A Contrastive Approach to the Types of Hedging Strategies Used in Norwegian and English Informal Spoken Conversations
}

\author{
Stine Hulleberg Johansen \\ Doctoral Research Fellow, University of Oslo, P.O. Box 1003 Blindern, \\ o315 OSLO, Norway \\ s.h.johansen@ilos.uio.no
}

\begin{abstract}
Hedging strategies, i.e. downtoning expressions or expressions of tentativeness or possibility, are ubiquitous in most, if not all, languages. However, hedging is often realised differently across languages, making such strategies particularly interesting to study from a contrastive perspective. The primary aim of this study is to compare the types of hedging strategies employed in Norwegian and English informal spoken conversations by using recently compiled corpus data. To enable a cross-linguistic comparison, a probe was used, i.e. a search term was devised to find other, surrounding elements in the corpora, and thereby retrieve comparable speech situations in which hedging strategies were likely to occur. The probe was successful in retrieving hedging strategies, and these strategies were then described by using a combination of categories from existing classificatory frameworks. The analysis uncovered several significant differences in the types of hedging strategies used in the two languages.
\end{abstract}

\section{Keywords}

hedging - English/Norwegian - classification - classificatory framework

The understanding of the concept of hedging has changed dramatically since it first became a topic of research interest in the 196os. Hedging has gone from being understood as a semantic feature of a class of words to a broad 
pragmatic concept encompassing nearly any expression of tentativeness or possibility, or with a softening or downtoning function. With this definition, hedging strategies are ubiquitous in both written and spoken discourse in most, if not all, languages, and hedging is considered to be an essential part of our pragmatic competence, i.e. the ability to "communicate your intended message with all its nuances in any socio-cultural context and to interpret the message of your interlocutor as it was intended" (Fraser, 2010:15). Pragmatic phenomena, such as hedging, are especially interesting to study from a contrastive perspective, because their realisations often do not correspond across languages (Romero-Trillo, 2018). For example in Norwegian, hedging may be expressed through modal particles, which, in most cases, do not have a direct translation in English (Johansson and Løken, 1997). This makes contrastive studies of hedging particularly relevant, because they "shine light on similarities and differences between languages and cultures" (Kaltenböck, Mihatsch and Schneider 2010: 2).

In studies of hedging strategies, classificatory frameworks, such as those of Prince, Frader and Bosk (1982) and Hyland (1996, 1998), are often used to describe and distinguish between strategies. Such frameworks say something about the type of hedging strategy, i.e. whether it concerns the relationship between parts of the proposition, between the speaker and the proposition, or between the speaker and the hearer. However, a challenge with many of the prevailing classificatory frameworks is that they are based on specific and often very formal types of discourse, such as physician-physician interaction (Prince et al., 1982), physician-patient interaction (Caffi, 1999), scientific articles from medical journals (Salager-Meyer, 1994) or scientific papers in molecular biology (Hyland, 1996). Most frameworks are also based exclusively on English data and were developed for analysing hedging in English. As a result, challenges arise when they are applied in studies of other discourse types and languages.

The purpose of this study is twofold. First, the study aims to identify similarities and differences in the types of hedging strategies used in Norwegian and English informal spoken conversations. To retrieve hedging strategies from Norwegian and English corpora, a probe, defined in Section 4.1, will be used. Hedging in Norwegian remains under-researched (Vold, 2006: 63), and the few studies on Norwegian that exist either investigate hedging in written discourse (e.g. Vold, 2006), or study hedging as one of several pragmatic functions of various pragmatic markers (e.g. Andvik, 1992; Berthelin and Borthen, 2019). In English, hedging has been studied from various perspectives and in various types of discourse (see Section 2 for further discussion); nevertheless, the majority of these studies are devoted to hedging in written discourse (e.g. Hyland, 1996; 
Markkanen and Schröder, 1997). Thus, there is still a need to investigate hedging in informal spoken language. Moreover, access to newly released corpora of informal spoken conversations in English, i.e. the spoken British National Corpus 2014 (Love, Dembry, Hardie, Brezina and McEnery, 2017), enables research on hedging in present-day English informal speech. This newly compiled corpus of contemporary spoken discourse provides a unique source for investigations into pragmatic phenomena such as hedging in authentic everyday conversations.

Second, to ensure a sound basis for the cross-linguistic comparison, an operational classificatory framework is needed to account for hedging strategies in Norwegian and English informal spoken conversations. To the author's knowledge, no classificatory framework has been established for hedging strategies in informal spoken language; however, existing classificatory frameworks provide valuable starting points for describing hedging strategies in informal discourse. Informed by corpus data, the framework used in this study will be based on four of the most prevailing hedging strategy classificatory frameworks, i.e. Prince et al. (1982), Hübler (1983), Hyland (1996, 1998) and Caffi (1999). ${ }^{1}$ The bilingual dataset is particularly important from the perspective of contrastive pragmatics as it ensures that the same classification scheme can be applied equally to both languages. The aims of the study can be summarised in two research questions:

1. What are the differences and similarities in the types of hedging strategies used in Norwegian and English informal spoken conversations?

2. To what extent can categories from existing classificatory frameworks be combined (and/or revised) to account for hedging strategies in Norwegian and English corpora of informal spoken conversations? Although RQ1 is this study's overarching research question, $\mathrm{RQ}_{2}$ must be addressed first in order to describe and classify the hedging strategies in the two languages. Both research questions will be discussed in the light of previous research on hedging in English and Norwegian as outlined in Section 2. The existing classificatory frameworks on which the proposed framework is built are described in Section 3. The approach and results of the contrastive study are outlined in Section 4. The data and methodological approach adopted will be presented in Section 4.1 and the results discussed in Sections 4.2.2 to 4.2.4. Some concluding remarks will be offered in Section 5 .

1 Caffi (1999) does not study hedging, but rather mitigation. However, mitigation overlaps to a great extent with hedging, when both concepts are defined in a broad sense. 
The start of hedging research in the mid-196os is often seen in connection with the introduction of fuzzy set theory (Zadeh, 1965) and the concept of metalinguistic operators (Weinreich, 1966). In fuzzy set theory, the boundaries between classes of objects are considered to be fuzzy, i.e. one can talk about degrees of class membership. For example a dog is a prototypical member of the class of animals, but bacteria would be a less prototypical member (Zadeh, 1965: 338). The term metalinguistic operators refers to words which signal how phenomena should be interpreted (Weinreich, 1966: 168). For example the word about can, in some contexts, indicate that something is an approximation. On the basis of this work, Lakoff (1972: 471), introduced the term hedge to describe words whose job is to modify the category membership of a word or phrase. The initial concept of hedging included both the attenuation and the reinforcement of class membership. Lakoff was mainly interested in the properties of this class of words and how they indicated the non-prototypicality of objects, i.e. made things more or less fuzzy. This type of hedging has later been referred to as propositional hedging in contrast to speech act hedging, which refers to hedges attenuating the strength of a speech act (Fraser, 2010). The speech act aspect of hedging was developed further through the work of Brown and Levinson (1987), who studied hedging to account for politeness phenomena in language use. They explained hedging as the application of a set of strategies which minimises the threat to the speaker's and hearer's face, i.e. their wish to be desired, and not imposed on, by others (Brown and Levinson, 1987: 62). The binary distinction between propositional hedging and speech act hedging has served as the foundation for several of the hedging strategy classificatory frameworks that were developed later.

The concept of hedging was broadened further as a result of the growing influence of pragmatic research from the 1980s onwards. The reinforcement aspect of hedging, introduced by Lakoff (1972), was pretty much laid aside (Fraser, 2010: 26), and hedging research became centred on the attenuation aspect. From the 1980s onwards, studies were conducted on the properties of individual hedging expressions (e.g. Aijmer, 1984). There were also several attempts to sub-classify hedges on the basis of various criteria (Fraser, 2010; Clemen, 1997) (see Section 3 for further discussion). The use of hedging expressions was studied in various genres of written discourse, particularly in academic texts (e.g. Salager-Meyer, 1994; Hyland, 1996, 1998), in learner language (e.g. Yang, 2013) and across languages and cultures (e.g. Tchizmarova, 2005; Kranich, 2011). Hedging has also been studied as a pragmatic function of certain expressions such as pragmatic markers (e.g. Jucker and Ziv, 1998; 
Andersen, 2001; Hasund, 2003), and as an aspect of related phenomena such as vague language (e.g. Channell, 1994; Jucker, Smith and Lüdge, 2003; Overstreet, 2011), modality (e.g. Holmes, 1982; Coates, 1987; Farr and O'Keeffe, 2002), and mitigation (e.g. Fraser, 1980; Caffi, 1999).

In the late 1970s and early 1980s, hedges also became an area of interest in Norwegian pragmatic research. The concept of dempere ('attenuators', 'hedges') was first mentioned in Fretheim (1979) and then further investigated in Fretheim (1981). Fretheim (1981) states that his mapping of various hedges in Norwegian is an attempt to make sense of a linguistic topic into which virtually no research had been conducted (Fretheim, 1981: 95). Since the 1980s, Norwegian hedging research has overlapped with research on pragmatic particles (e.g. Andvik, 1992; Hasund, 2003; Berthelin and Borthen, 2019). Such studies have been important in understanding how hedging is realised in Norwegian, but more research is needed to understand how hedging is expressed in Norwegian beyond the use of pragmatic particles. To the author's knowledge, the only study devoted primarily to hedging in Norwegian is that of Vold (2006), who compares the use of epistemic modality markers in Norwegian, English and French scientific articles.

The development reflected in this extensive body of research has resulted in a much wider definition of hedging than the one proposed by Lakoff (1972). Today, hedges are mainly regarded as "realizations of an interactional/communicative strategy" (Markkanen and Schröder, 1997: 5). The concept of "fuzziness" in the Lakoffian sense has been expanded to also include elements such as uncertainty, lack of precision and lack of commitment of the speaker to the propositional content (Prokofieva and Hirschberg, 2014:1). Furthermore, the idea of a grammatical class of hedges has been abandoned and there is now general agreement that "no linguistic items are inherently hedgy" (Clemen, 1997: 241) and that "hedging devices are drawn from every syntactic category" (Fraser, 2010: 23).

Although most researchers now agree that hedging is some form of strategy, the definitions applied in studies of hedging still vary in some respects. Some definitions are formulated from a speaker-oriented perspective, for example Fraser (2010: 22), where hedging is described as a "rhetorical strategy, by which a speaker [...] can signal a lack of commitment to either the full semantic membership of an expression [...] or the full commitment to the force", whereas others also include the perspective of the hearer. For example, Holmes (1982: 9), states that hedging is a linguistic device used by speakers to express their attitudes to the proposition and "to reflect their perceptions of their relationship to those listening". Hyland (1998: 1) defines hedging as any linguistic means indicating a lack of commitment to the truth 
of a proposition, or a desire to not "express that commitment categorically". Although the interlocutor is not explicitly mentioned in this definition, Hyland (1996: 446) explains how hedging has an interpersonal function and is used to appeal to the reader. Similarly, Tchizmarova $(2005: 1146)$ understands hedging as a strategy that "mitigates the harshness or hostility of the force of one's actions, softens the force of utterances and makes them more acceptable to the hearer." This appellative aspect of hedging has also been discussed in connection with the functions of Norwegian pragmatic markers. Fretheim (1981: 87-88) distinguishes between ego-dempere ('ego-hedges') and alter-dempere ('alter-hedges'), arguing that certain expressions used to express the speaker's uncertainty also implicitly seek confirmation from the hearer.

In this study, hedging is understood to be the discourse strategies that reduce the force, truth or perceived negative effect of an utterance on the hearer. This view encompasses the hearer-oriented focus mentioned in Fretheim (1981), Hyland (1996) and Tchizmarova (2005), and thus goes beyond the distinction between hedging within the proposition and hedging between the speaker and the proposition, which characterises many hedging studies.

\section{$3 \quad$ Hedging Strategy Classificatory Frameworks}

The first exhaustive attempts to create a framework for the classification of hedges were undertaken in the early 1980s. The purpose of such frameworks was to divide hedges into subcategories to enable the nature and scope of various hedging strategies to be better understood. Fraser (2010) mentions some 20 suggested subcategories from various classificatory frameworks that were developed from the 198 os onwards. However, only some of these frameworks, described in further detail below, have been, and continue to be, widely applied in studies of hedging strategies. In this paper, I will attempt to combine categories from existing classificatory frameworks into a revised framework for hedging in spoken conversations in order to account for the hedging strategies that are used in Norwegian and English informal spoken conversations.

Prince et al. (1982) developed the first widely acknowledged framework for hedging in spoken interaction. Their framework arose from research on a corpus of interactions between physicians working in a paediatric ward. They base their understanding of hedges on Lakoff's (1972) concept of fuzziness, but distinguish between two types of fuzziness, i.e. within the propositional content and in the relationship between the speaker and the content. These two types of hedging strategies are further subdivided into four categories: adaptors, rounders, plausibility shields and attribution shields. Adaptors indicate 
non-prototypicality and may be used when the speaker adapts an existing word to a new situation, e.g. His feet were sort of blue. Rounders are used when the speaker does not want or need to give exact information, e.g. His weight was approximately 3.2 kilograms. Both are used to indicate that the actual situation is not identical to, but is close to, the prototypical situation (Prince et al., 1982: 11). Plausibility shields indicate uncertainty on behalf of the speaker towards the content of the proposition, e.g. I think his feet are blue. Attribution shields are used when the speaker wants to attribute the belief expressed in the proposition to someone else, e.g. According to her estimates, the heart rate was back in two minutes. Prince et al.'s (1982) system has also inspired later attempts to establish classificatory frameworks, such as that of Salager-Meyer (1994), who uses labels such as adaptors, rounders and shields in her description of the hedging strategies employed in English medical discourse.

This same binary distinction between hedging within the proposition and hedging between the speaker and the proposition is found in Hübler (1983), who authored the first monograph on hedges. He argues that hedges may be used to express "the attitude of the speaker to the hearer regarding the proposition" (p. 11) and distinguishes between understatements and hedges, where understatements concern the propositional content, i.e. the phrastic part of the sentence, and hedges concern the speaker's claim to the validity of the proposition, i.e. the neustic part of the sentence. However, Hübler's distinction has received little support as understatements are commonly regarded to be a subcategory of hedges (Clemen, 1997: 241).

The related phenomenon of mitigation strategies can also be subdivided into different types depending on their scope in the speech act. Mitigation was originally defined as the reduction of the unwelcome effects of a speech act on the hearer (Fraser, 1980: 341), but is now regarded as a synonym for weakening, downgrading and downtoning (Caffi, 1999: 884). Although mitigation and hedging have been regarded as two different concepts (Fraser, 1980: 344), the broadening of these concepts has caused them, to a large extent, to overlap, and thus mitigation frameworks are also relevant to the study of hedging strategies. Caffi (1999) developed a framework for describing mitigation strategies which bears a resemblance to Prince et al.'s (1982) framework. Caffi (1999) distinguishes between mitigation on the proposition, bushes, mitigation on the illocution, hedges, and mitigation on the utterance source, shields, i.e. hiding the mitigating operator. This category of shields is related to what Prince et al. (1982) call attribution shields. However, whereas Prince et al. (1982) include lexical expressions attributing a belief to someone else in this category, Caffi (1999: 896) also includes complete deletion of the source, for example as seen in passive clauses where the agent responsible for the action is hidden in the 
syntactic structure. Like Prince et al. (1982), Caffi (1999) also uses medical discourse data. The latter studies data taken from a corpus of transcripts of doctor-patient and psychotherapeutic conversations, but in Italian rather than English.

Although Hyland (1996) studied hedging in written discourse, his framework is also relevant when analysing spoken conversations, as it contains a category which neither Prince et al. (1982) nor Caffi (1999) include, i.e. readeroriented hedges. Hyland (1996) distinguishes between content-oriented and reader-oriented hedges where the former concern the relationship between the proposition and a representation of the world, and the latter are hedges that seek acceptance by the reader for a claim made by the writer and have an interactional function in this respect (Hyland, 1996: 446). Content-oriented hedges are further subdivided into accuracy-oriented and writer-oriented hedges (Hyland, 1996: 436-437). The former type concerns hedges expressing uncertain scientific claims with appropriate caution to reduce the risk of refutation, e.g. The EGTA clots are possibly comprised of thinner fibres than $[\ldots]$. The latter type concerns hedges that enable the writer to guard himself/ herself against criticism, e.g. The figures suggest that [...]. Accuracy-oriented strategies are further subdivided into attribute hedges indicating the extent to which propositional content is precisely described, and reliability hedges indicating the degree of writer confidence. Reader-oriented hedges attend to the acceptability of statements to the hearer and share some characteristics with the alter-hedges proposed by Fretheim (1981). The categories proposed by Hyland $(1996,1998)$ have been criticised for overlapping and being difficult to distinguish (Diewald, 2006); nevertheless, his framework is widely adopted in studies of hedging in scientific discourse.

Overall, the classificatory frameworks identify five main areas in which hedging takes place. Table 1 summarises the labels that are used in the different frameworks and how they overlap. These five areas and the corresponding subcategories of hedging strategies were used as a point of departure for the analysis of the Norwegian and English corpus data (described in Section 4). The labels that were applied in this study are presented in the bottom row of Table 1.

The material in this study shared some features with the spoken data used in Prince et al. (1982), and therefore the labels rounders, adaptors and shields were used in conjunction with the definitions proposed by Prince et al. (1982) (see above). For those hedging strategies which could not be labelled according to Prince et al. (1982), labels from other frameworks were used. The choice of label was based on the degree to which the hedging strategies found in the data fitted the description of the category. Each category is discussed and exemplified in Sections 4.2.2-4.2.4. 
TABLE 1 Subtypes of the various hedging strategies in the literature

\begin{tabular}{|c|c|c|c|c|c|}
\hline & $\begin{array}{l}\text { Propositional } \\
\text { content }\end{array}$ & $\begin{array}{l}\text { Speaker } \\
\text { intention }\end{array}$ & $\begin{array}{l}\text { Speaker } \\
\text { commitment }\end{array}$ & $\begin{array}{l}\text { Source } \\
\text { (of the } \\
\text { proposition) }\end{array}$ & $\begin{array}{l}\text { Effect } \\
\text { on the } \\
\text { interlocutor }\end{array}$ \\
\hline $\begin{array}{l}\text { Fretheim } \\
(1981)\end{array}$ & & & Ego-hedges & & Alter-hedges \\
\hline $\begin{array}{l}\text { Prince, } \\
\text { Frader } \\
\text { and Bosk } \\
(1982)\end{array}$ & $\begin{array}{l}\text { Approximators - } \\
\text { Rounders and } \\
\text { Adaptors }\end{array}$ & & $\begin{array}{l}\text { Shields } \\
\text { (Plausibility) }\end{array}$ & $\begin{array}{l}\text { Shields } \\
\text { (Attribution) }\end{array}$ & \\
\hline $\begin{array}{l}\text { Hübler } \\
(1983)\end{array}$ & Understatements & & Hedges & & \\
\hline $\begin{array}{l}\text { Salager- } \\
\text { Meyer } \\
(1994)\end{array}$ & Approximators & & $\begin{array}{l}\text { Shields, } \\
\text { Author's per- } \\
\text { sonal doubt }\end{array}$ & & \\
\hline $\begin{array}{l}\text { Hyland } \\
(1996, \\
1998)\end{array}$ & $\begin{array}{l}\text { Content-oriented } \\
\text { hedges - Attribute } \\
\text { hedges }\end{array}$ & & $\begin{array}{l}\text { Content- } \\
\text { oriented } \\
\text { hedges - } \\
\text { Reliability } \\
\text { hedges, } \\
\text { Writer- } \\
\text { oriented } \\
\text { hedges }\end{array}$ & $\begin{array}{l}\text { Writer- } \\
\text { oriented } \\
\text { hedges }\end{array}$ & $\begin{array}{l}\text { Reader- } \\
\text { oriented } \\
\text { hedges }\end{array}$ \\
\hline $\begin{array}{l}\text { Caffi } \\
(1999)\end{array}$ & Bushes & Hedges & Hedges & Shields & \\
\hline $\begin{array}{l}\text { The } \\
\text { present } \\
\text { study }\end{array}$ & $\begin{array}{l}\text { Rounders, } \\
\text { Adaptors, } \\
\text { Understaters }\end{array}$ & \multicolumn{2}{|c|}{$\begin{array}{l}\text { Plausibility shields, } \\
\text { Speaker-oriented hedges }\end{array}$} & $\begin{array}{l}\text { Attribution } \\
\text { shields }\end{array}$ & $\begin{array}{l}\text { Hearer- } \\
\text { oriented } \\
\text { hedges }\end{array}$ \\
\hline
\end{tabular}

\section{Comparing the Use of Hedging Strategies in Norwegian and English Informal Spoken Conversations}

The following sections present the contrastive study. Section 4.1 describes the material and the methodological approach used to retrieve the hedging strategies. Section 4.2 presents the classification of the hedging strategies and discusses any differences and similarities between the two languages. 


\subsection{Material and Method}

The material used in this study consists of three corpora of spoken Norwegian conversations, The Norwegian Speech Corpus (NoTa), the BigBrother Corpus (вв) and the Norwegian part of the Nordic Dialect Corpus (NDC), and the spoken British National Corpus 2014 (BNC2014). These corpora were chosen because of their degree of comparability and their availability. The corpora are not directly comparable with respect to the manner in which they were compiled or their size, but each corpus was compiled between 2001 and 2016 and includes the same types of texts, i.e. natural conversations between family members, friends, acquaintances and strangers. The size of each corpus is presented in Table 2 (see the websites listed after the Reference section for further information.)

Realisations of the hedging strategies were retrieved through a bottom-up approach by using a probe. A probe can be defined as an element, e.g. a tag, a word or a string of words, which is used to find other elements that cannot otherwise be easily found in a corpus (Hunston, 2002: 62). The idea was thus to use a probe as a tool to retrieve a wide range of hedging strategies without searching for their actual realisations. In this study, the contrastive conjunction but (English) and its Norwegian counterpart men were used as a probe (Johansen, 2019). The choice of probe was based on the assumption that hedging strategies are often used for politeness purposes in spoken conversations to avoid threatening the hearer's face or damaging the speaker's face (Nikula, 1997: 192), and that expressing a contrasting view, for example introduced by men/ but, could potentially be face-threatening. Therefore, it was deemed likely that hedging strategies would occur in the proximity of a contrastive marker such as men/but. ${ }^{2}$ This approach does not capture all potential realisations of the hedging strategies in a corpus, but retrieves a variety of different strategies and thus gives an insight into how hedging is expressed in both languages. Furthermore, it ensures that similar speech situations are compared across the corpora.

In total, 8 oo occurrences of but and 8 oo occurrences of men were retrieved randomly from the corpora, by using the random selection settings in the corpus interfaces. ${ }^{3}$ Table 2 shows the total number of hits for the probe as well as the randomised samples. Subsequently, all 1600 instances obtained by the probe were examined manually and their contrastive uses identified. The material yielded 582 contrastive uses of men and 659 contrastive uses of but.

2 See Johansen (2019) for an extensive overview of the identification of probes.

3 These were Glossa for the Norwegian corpora (https:/www.hf.uio.no/iln/english/about/ organization/text-laboratory/services/glossa/) and CQPweb for BNC2O14 (https://cqpweb. lancs.ac.uk/). 


\begin{tabular}{|c|c|c|c|c|c|c|}
\hline & $\begin{array}{l}\text { Total no. } \\
\text { of words }\end{array}$ & $\begin{array}{l}\text { Total no. } \\
\text { of 'but/ } \\
\text { men' con- } \\
\text { cordance } \\
\text { lines } \\
\text { in the } \\
\text { sample }\end{array}$ & $\begin{array}{l}\text { Total } \\
\text { no. of } \\
\text { randomly } \\
\text { selected } \\
\text { 'but/men' }\end{array}$ & $\begin{array}{l}\text { Total no. } \\
\text { of con- } \\
\text { trastive } \\
\text { 'but/men' } \\
\text { concor- } \\
\text { dance } \\
\text { lines }\end{array}$ & $\begin{array}{l}\% \text { of } \\
\text { contrastive } \\
\text { uses co- } \\
\text { occurring } \\
\text { with } \\
\text { hedging } \\
\text { strategies }\end{array}$ & $\begin{array}{l}\text { Total no. } \\
\text { of hedging } \\
\text { strategies } \\
\text { co-occurring } \\
\text { with 'but/ } \\
\text { men' }\end{array}$ \\
\hline NoTa & 674,596 & 8,210 & 266 & 186 & $64 \%$ & 253 \\
\hline В В & 440,354 & 5,854 & 267 & 193 & $55 \%$ & 195 \\
\hline NDC & $1,199,651$ & 14,280 & 267 & 203 & $62 \%$ & 229 \\
\hline $\begin{array}{l}\text { Total Norw. } \\
\text { corpora }\end{array}$ & $2,314,601$ & 28,344 & 800 & 582 & $6 \circ \%$ & 677 \\
\hline $\mathrm{BNC}_{2014}$ & $11,422,617$ & 103,439 & 800 & 659 & $53 \%$ & 762 \\
\hline
\end{tabular}

But and men were mainly considered contrastive when they denoted denial of expectation, opposition of two elements (antithetic use), modification or explanation of a previous statement, restriction of a previous statement, or when a speaker objected to something said by another speaker. Any instances where but/men were not used in their contrastive sense, but, for example, were used as a discourse marker to structure units of talk or as a topic changer, were disregarded. Following the identification of the contrastive uses of the probe, potential hedging strategies were identified to the right of the probe, as illustrated in Figure 1.

The example in (1) illustrates the use of the probe, but, and a co-occurring hedging strategy, kind of, to the right of the probe.

(1)

[...] in my mind I was thinking he's he's most likely dead but I kind of hoped that he wasn't

BNC2014 text: $\mathrm{S}_{7} \mathrm{BR}$ no. 748

As shown in Table $2,60 \%$ of the 582 contrastive uses of men co-occurred with hedging strategies, and of the 659 contrastive uses of but, $53 \%$ co-occurred with hedging strategies. Several of the contrastive uses of but and men cooccurred with more than one hedging strategy. This gave a total of 1,439 hedging strategies to be categorised. 


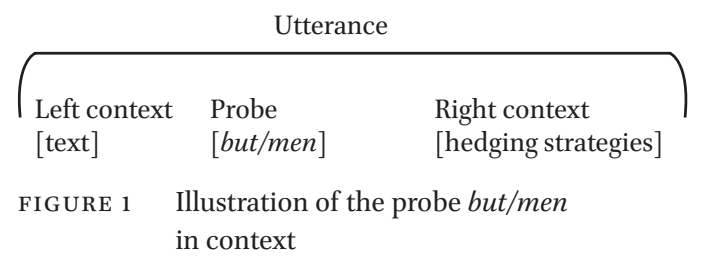

\subsection{Results and Discussion}

This section presents the overall results of the classification by providing some quantitative data in Section 4.2.1 and a more detailed qualitative discussion of the subcategories with examples from both the English and Norwegian corpora $^{4}$ in Sections 4.2.2-4.2.4.

\subsubsection{Overall Classification and Comparison}

Overall, the material can be grouped into three main types of hedging: within the proposition, between the speaker and the proposition, and between the speaker and the hearer. Subsequently, an attempt was made to sub-classify the strategies using terminology from the existing classificatory frameworks outlined in Section 3. Compared to the results of a pilot study using Prince et al's (1982) classification system (Johansen, 2018), the present framework performed very well in that it was able to account for the whole dataset and did not classify a substantial part of it as 'miscellaneous'. The outcome of the classification is presented in Table 3 and illustrated in Figure 2. For each subcategory, the two languages have been compared using a log-likelihood test. ${ }^{5}$ The p-values are shown in the rightmost column.

\subsubsection{Propositional Hedging Strategies}

Propositional hedging strategies can be divided into three subcategories: rounders, adaptors and understaters. An example of a rounder is given in (2). Like has an approximative function indicating that an hour and a half is an approximate estimate of time. Similarly, in (3), en plass ('a place', 'somewhere') signals an approximate location. Kind of in (4) is an example of an adaptor which modifies freaked (me) out. An interpretation of this example may be that the speaker was shocked by what she had read, but perhaps not to the extent that she completely lost control or panicked, as the choice of verb, freak out,

4 The examples are written as they are transcribed in the respective corpora. Transcription symbols are explained in the footnotes. See also Hagen (2008) and The BNC2014 User Manual and Reference Guide (2018) for an overview of the transcription symbols used in the corpora.

5 http://ucrel.lancs.ac.uk/llwizard.html. 


\begin{tabular}{|c|c|c|c|c|c|c|}
\hline & & Norwegian & & English & & \\
\hline & $\begin{array}{l}\text { Types of hedging } \\
\text { strategies }\end{array}$ & $\begin{array}{l}\text { Raw } \\
\text { frequencies }\end{array}$ & $\%$ & $\begin{array}{l}\text { Raw } \\
\text { frequencies }\end{array}$ & $\%$ & p-value \\
\hline \multirow{3}{*}{$\begin{array}{l}\text { Within the } \\
\text { proposition }\end{array}$} & Rounders & 67 & $9 \cdot 9$ & 115 & 15.1 & $\mathrm{p}<0.01$ \\
\hline & Adaptors & 63 & $9 \cdot 3$ & 94 & 12.3 & NS \\
\hline & Understaters & 92 & 13.6 & 68 & 8.9 & $\mathrm{p}<0.01$ \\
\hline \multirow{3}{*}{$\begin{array}{l}\text { Between } \\
\text { the speaker } \\
\text { and the } \\
\text { proposition }\end{array}$} & $\begin{array}{l}\text { Plausibility } \\
\text { shields }\end{array}$ & $15^{\circ}$ & 22.2 & 190 & $24 \cdot 9$ & NS \\
\hline & $\begin{array}{l}\text { Attributions } \\
\text { shields }\end{array}$ & 4 & o.6 & 2 & 0.3 & $\mathrm{~N} / \mathrm{A}^{\mathrm{a}}$ \\
\hline & $\begin{array}{l}\text { Speaker-oriented } \\
\text { hedges }\end{array}$ & 106 & $15 \cdot 4$ & 197 & $25 \cdot 9$ & $\mathrm{p}<0.0001$ \\
\hline \multirow{2}{*}{$\begin{array}{l}\text { Between the } \\
\text { speaker and } \\
\text { the hearer }\end{array}$} & $\begin{array}{l}\text { Hearer-oriented } \\
\text { hedges }\end{array}$ & 195 & 28.8 & 96 & 12.6 & $\mathrm{p}<0.0001$ \\
\hline & & 677 & $\approx 100$ & 762 & $\approx 100$ & \\
\hline
\end{tabular}

a This category has not been tested for significance due to the low number of occurrences in both languages.

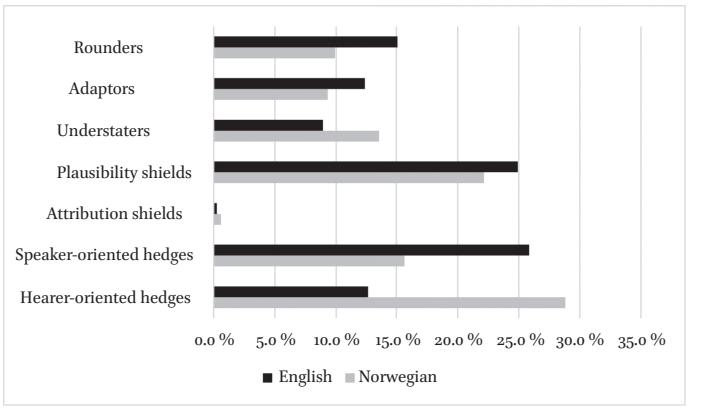

FIGURE 2

Overview of the distribution of categories in Norwegian and English

could indicate. The use of kind of signals that the actual situation is close to, but not identical to, the prototypical situation of freaking out (Prince et al., 1982: 11). Sånne [perioder] in (5) is another example of an adaptor. The speaker here may be uncertain about whether the term perioder ('periods') is the appropriate term to use or he decides that the exact term is not relevant and chooses the closest relevant term (Prince et al., 1982: 9). This adaption is marked by sånne ('such', 'like'). 
(2)

Schools will close the kids will be out at half past one and then they have to be back for half past three but it's crazy cos then they go back for like an hour and a half

BNC2O14 text: S2XJ no. 361

$(3)^{6,7}$

[... ] men det viste seg det at han gikk inn der fikk ut der og der lå det et lite fiskebein \# som hadde satt seg fast i spiserøret en plass

'[...] but it turned out that he went in there and got out there and there there was a small fishbone \# which had gotten stuck in the oesophagus somewhere'

NDC no. 553 (nes_o3gm ><who_avfile nes_o3gm-04gk)

\section{$(4)^{8}$}

I read I read it a bit wrong (.) I don't know what I read but it kind of freaked me out and made me stop

BNC2014 text: SFP5 no. 364

(5)

[...] så bodde jeg da disse sju årene i Afrika da men det var da m med sånne \# perioder hjemme imellom

'[...] so then I lived then these seven years in Africa but it was then $m$ with like \# periods home in between'

NoTa no. 825 (o7o><who_avfile o69-070)

Rounders and adaptors in Prince et al. (1982) are related to (non-)prototypicality. In the material, however, a type of hedging strategy with a propositional scope was observed which did not indicate (non-)prototypicality and therefore could not be labelled as either a rounder or an adaptor. Expressions employing this hedging strategy seemed to downplay the importance of the whole proposition (or parts of it) and could be said to have a dual function in that they both modify a concept locally, but at the same time mitigate the force of the utterance to make it less of a burden on the hearer. As a result of this potential

6 Glosses of the Norwegian examples are provided by the author in single quotation marks.

7 The \# symbol indicates a short pause.

8 The (.) symbol indicates a short pause. 
dual-function, such expressions have been categorised separately and labelled as understaters, in line with Hübler (1983: 70) who states that understaters are expressions which have a detensifying effect on the phrastic part of a sentence or utterance. Understaters are typically used to under-represent the state of affairs (Markkanen and Schröder, 1997: 7) and can have both a propositional and a relational scope.

In (6) speaker B interrupts speaker A by objecting to what speaker A is saying, which may be perceived as face-threatening. However, by suggesting that the river is only a bit ('litt') wider, the force of the objection is reduced and may be easier to accept. Litt says something about the size of the river and thus has a propositional scope.

A: ja ja ja veldig gøy det passa fint i i de strykene der

B: *men det var

B: litt bredere bredde på den elva da

'A: yes yes yes a lot of fun it fitted nicely in those rapids there

B: *but there was

B: a bit of a wider riverbank on that river then'

NoTa no. 1037 (101><who_avfile 101-102)

Comparing the two languages, the results show that English speakers used significantly more rounders than Norwegian speakers, whereas Norwegian speakers used significantly more understaters than English speakers (Table 3). The English expressions that were classified as rounders were typically vague quantifiers, such as a lot of and a number of, and vague nouns, such as thing and stuff. The reasons why there are a high number of these expressions are unclear. In a study of vague expressions, Jucker et al. (2003: 1755) state that "it is a challenge to explain why so many vague expressions for describing frequency exist in English" but suggest that it may be to indicate that the exact number is not relevant. The high number of understaters in Norwegian may be related to what has been referred to as the "distance rule of politeness" in Norwegian (Rygg, 2017: 2), in which it is argued that Norwegians show consideration by not imposing on other people, and this may also be reflected in the use of understaters to tone down the importance of the message.

4.2.3 Hedging between the Speaker and the Proposition

Hedging strategies indicating uncertainty on the part of the speaker were frequent in both languages. Expressions indicating uncertainty have been 
labelled as plausibility shields, and examples (7), (8) and (9) show some of the forms in which these plausibility shields occurred. Several different types of hedging strategies occur together in (7). Kanskje ('maybe'), which occurs twice, is an example of a plausibility shield. As described in Prince et al. (1982: 11), shields imply that the speaker is not fully committed to the truth of the proposition. Liksom ('like'), which has a hedging function (Beeching, 2016: 128; Hasund, 2003), and the general extender og sånn ('and so on') will be discussed in more detail below. Litt ('a bit') functions as a propositional understater here and modifies the degree to which women decide matters. Examples (8) and (9) use the expression I think and the superficially similar jeg tror as plausibility shields. In (8), speaker A is objecting to what speaker B is saying. In this case, no signals agreement, but then the agreement is modified by but. Speaker A modifies his argument by not fully committing to the proposition. In example (9) speaker A is turning down her own suggestion, after speaker B has indirectly turned it down, by suggesting something else.

(7)

før i tida \# så var det kvinnfolka som var hjemme og sånn og sånn så _ uforståelig_ men nå er liksom \# nå er blitt mer sånn \# nå \# det kanskje kvinner som bestemmer \# kanskje til_og_med litt mer \# hun kjefter og liksom sånn og sånn og sånn

'back in the day \# it was the women who were home and so on and so on _incomprehensible_but now is like \# now is has become more like \# now \# it maybe women who decide \# maybe even a bit more \# she scolds and like stuff and so on and so on'

в в no. 222 (Ramsy ><who_avfile 5)

A: >> yeah yeah yeah but the other thing is they don't know how to write CVs and they actually don't know

B: mm I'm not I've seen millions of cVs and I'm going to be honest I'm not sure if $\mathrm{I}$ know the right $\mathrm{CV}$

C: >> --UNCLEAR WORD well I do think I think that's that's a problem everybody has but erm

A: > no but $I$ think it's easier when you're at an --UNCLEAR WORD

BNC2014 text: SA6K, no. 431

(9)

A: kanskje vi skal lage et lite prosjekt rundt det?

B: det er så lite kaffeplanter i Norge vet du det er det_uforståelig 
A: * ja * ja men ja ja m \# nei men vi jeg tror vi skal prøve å eksperimentere med litt andre ting jeg

'A: maybe we should make a small project around it?

B: there are so few coffee plants in Norway you know it is it_incomprehensible_

A: *yes *yes but yes yes $\mathrm{m}$ \# no but we I think we should try to experiment with some other things I'

NoTa no. 1043 (102><who_avfile 101-102)

One type of strategy which rarely occurred in the material was what is referred to as attribution shields, shields and writer-oriented hedging strategies, i.e. attributing the belief to someone else or hiding the source of the proposition. This type of strategy is illustrated in example (10). The lack of such examples in the material may be due to the type of data being investigated. Hyland (1996) states that writer-oriented hedges are used when a writer wishes to avoid personal responsibility for the proposition, which is a common characteristic of scientific texts where one's work is supposed to build on the previous work of others. Prince et al. (1982) state that attribution shields are primarily used to relate background information to the present situation, typically the reason for hospitalisation, which is natural in a hospital setting. Although Prince et al. (1982: 19) maintain that attribution shields also occur in other domains, they do not substantiate this claim.

(10)

A: er Yuri Gagarin and people like that

B: yeah that's right (.) and was that proved? Proven to have been faked?

A: no there's no question marks about that because they didn't actually make it get it to the moon (.) but

B: right

A: but it according to this book if I remember correctly they they were genuine

BNC2O14 text: SVBJ no. 543

Strategies which say something about the speaker's commitment to the force or content of the proposition were labelled speaker-oriented hedging strategies, and corresponded, in part, to the writer-oriented hedges in Hyland (1996). These strategies do not indicate uncertainty, but a common denominator of many of these strategies was that they seem to create distance between the speaker and the proposition. In example (11), speaker A downplays his/her opinion about the food by stating that he/she is not an expert on Chinese 
restaurants. In (11), the whole clause functions as a hedge. In example (12), speaker A reduces the commitment to the proposition by using liksom ('like') in the clause-final position. Liksom in the clause-final position can have a hedging effect on the preceding expression (Hasund, 2003: 199).

(11)

I mean it really is uh (.) the quality of the food I thought was really good (.) but (.) but I'm not um I'm not an expert on Chinatowns of course we don't have a Chinatown here

BNC2O14 text: SWMV no.582

Nei men du kommer deg mye mer fram med trikken liksom spesielt nå som den går hver femte minutt

'No but you get there more easily by tram like especially now when it departs every five minutes'

NoTa no. 964 (o3o><who_avfile o29-03o)

Speaker-oriented hedging strategies were significantly more frequent in the English data than in the Norwegian data. A contributing factor could be the frequent use of like to signal lack of commitment. Like is very common in informal speech and is often used to downplay a potentially dogmatic delivery and hedge a potentially critical stance adopted by the speaker (Beeching, 2016: $132,134)$. The like used in (13) is an example of a softening like.

A: I could take you out for a special breakfast at some point

$[\ldots]$

A: the --ANONplace?

$[\ldots]$

B: yeah but we won't want to get a little closer to it er like so we don't have to walk ages cos it makes me really hungry

BNC2O14 text: S839 no.346

4.2.4 Hedging between the Speaker and the Hearer

Hedging on the relationship between the speaker and the audience is only included in Hyland's (1996) framework. Still, this type of hedging occurred frequently in the material. It seems as if speakers tend to be very aware of their interlocutor and maintaining a good relationship between the interlocutors 
is a priority. In general, this is accomplished by trying to establish common ground between the speaker and the hearer. In example (14) speaker A uses you know in the clause-final, but utterance-medial position. In the medial position, you know can be used to invite co-construction of the content or the formulation of the message (Beeching, 2016: 97). The general function of the pragmatic marker you know is to appeal to actual or fictive common knowledge between the interlocutors (Beeching, 2016: 98). By combining the second person pronoun, you, with the cognitive verb, know, it has a stronger appeal to the addressee (Beeching, 2016: 98).

A: I'd like to be lecturer

B: yeah er

A: >> and I don't mind the first years but I'd like to mix them with (.) kind of fourth years and masters students you know so you get a bit more of a spread cos you get intolerant of (.) I shouldn't you know but

BNC2O14 text: SEPP no. 324

Hedging strategies on the relationship between the speaker and the hearer occurred significantly more often in the Norwegian material than in the English material (Table 3). A reason for this may be the Norwegian particle jo ('after all', 'of course') which shares some of the pragmatic functions of you know. Jo occurs frequently in informal spoken language (Berthelin and Borthen, 2019: 1) and has traditionally been considered to indicate some sort of 'givenness'. It can be interpreted as a way of establishing a mutual manifest between the speaker and the hearer (Berthelin and Borthen, 2019). The jo in example (15) may be interpreted as an assertion of common ground between the speakers.

A: det er i Oslo \# så er det sånn t- sånn noe ruiner av et sånt kloster der_inne

B: ja men det i Trondheim har jo vært der lenge $d a$

'A: it is in Oslo \# so it is like t- like some ruins from a like convent in there B: yes but the one in Trondheim has [pragmatic particle] been there for a long time [pragmatic particle]' в в no. 23 (Lars_Joakim $><$ who_avfile 12)

A challenge with the Norwegian particles is that they may serve more than one function simultaneously, and it can be difficult to determine their exact 
pragmatic function and meaning. A particularly challenging particle is $d a$ ('then', 'consequently', 'right?') which also occurs in (15). The effect of the use of $d a$ is to a large degree dependent on the context in which it occurs, and ranges from modifying and questioning to being assertive and having a strengthening effect on the proposition (Borthen, 2014: 257).

Another example of how a speaker may seek agreement or solidarity with the hearer can be found in example (7). The general extender og sånn ('and so on') can serve a variety of functions, not all of which will be discussed here. In this example, a likely interpretation could be that it indicates a wider semantic scope (Andersen, 2010), i.e. the speaker is only mentioning one of several activities, kjefter ('scolds'), or that it serves as a marker of positive politeness inviting solidarity between the speaker and the hearer (Overstreet, 1999: 146).

Tag questions may also serve a hedging function. In particular, asymmetrical tag questions (with opposite polarity) with rising intonation can indicate uncertainty or doubt on behalf of the speaker (Hübler, 1983: 108-109) or is a way of inviting the hearer into the conversation and thus creating common ground (Brown and Levinson, 1987: 101). Tag questions with falling intonation may also assert common ground, e.g. by presupposing that the speaker and the hearer share certain knowledge (Brown and Levinson, 1987: 103). Excerpt (16) is an example of an asymmetrical tag question, which could be interpreted as the speaker seeking confirmation from the interlocutor. In (16) the speakers are discussing the Brexit vote and speaker $\mathrm{B}$ uses both the understater $a$ bit and the tag-question wasn't I to modify his/her statement.

A: what did you vote then?

B: I voted in but I'm saying I would be more ha- I was saying I was a bit on the fence wasn't I? I'd be more happy about it if if we would have more control over what we do as a country

BNC2014 text: S8CV no. 59

\section{5}

\section{Concluding Remarks}

The purpose of this study was twofold. The primary aim was to discover similarities and differences in the use of hedging strategies in Norwegian and English informal spoken conversations by using recently compiled corpus data. Second, in order to compare strategies across the two languages, the existing hedging strategy classificatory frameworks needed to be revised and adapted so that they could be used in the analysis of informal spoken conversations. 
The majority of these frameworks were based on formal spoken or written language, mainly in English, and thus were not directly applicable to informal spoken language.

In summary, the results show that existing classificatory frameworks can be used to account for hedging strategies in Norwegian and English spoken conversations, but more than one framework is necessary and challenges arise when frameworks that are based on other types of discourse are applied to contrastive conversational data. For example, categories, such as attribution shields (Prince et al., 1982), shields (Caffi, 1999) and a subtype of speaker-oriented hedges (Hyland, 1996), ${ }^{9}$ which are thoroughly described and exemplified in the descriptions of their respective frameworks, were scarce in the conversational data. Conversely, examples of hearer-oriented hedges (Hyland, 1996) ${ }^{10}$ occurred frequently in the data, but are only included in one of the classificatory frameworks. Another challenge encountered when classifying hedging strategies was distinguishing between the different subcategories. Many of the forms used to express hedging, such as several of the Norwegian particles, may serve different functions simultaneously and thus may be challenging to classify.

The threefold distinction of hedging strategies, i.e. within the proposition, between the speaker and the proposition and between the speaker and hearer, challenges the binary distinction on which many of the classificatory frameworks are built. However, the inclusion of the speaker-hearer dimension highlighted some interesting cross-linguistic differences in the data. The results showed that English speakers used significantly more speaker-oriented hedging strategies than Norwegian speakers. This may be due to the frequent use of like to signal lack of commitment in informal conversations. Norwegian speakers used significantly more hearer-oriented strategies. This difference could be related to the appellative aspect of many of the Norwegian modal particles that are often used for hedging purposes, such as jo, for which there is no literal English translation and which is very common in informal spoken language. Within the propositional hedging category, the results also showed that English speakers used significantly more rounders than Norwegian speakers and that Norwegian speakers used more understaters than English speakers. Future studies - preferably including hedging strategies in different types of context, and in different discourse types and languages - will test the more general applicability of the classificatory framework being proposed here.

$9 \quad$ Referred to as writer-oriented hedges in Hyland (1996).

10 Referred to as reader-oriented hedges in Hyland (1996). 


\section{Biographical Note}

Stine Hulleberg Johansen is a Doctoral Research Fellow at the University of Oslo. She is currently working on a research project on hedging strategies in Norwegian and English informal spoken conversations using corpus-based and corpus-driven methods, where she is comparing how native speakers of Norwegian, native speakers of English and Norwegian learners of English use hedging strategies to lessen the impact of their utterances on their interlocutors.

She has an MA in English language from the University of Oslo and has worked as an adviser for research projects funded by the European Commission's framework for research and innovation.

\section{References}

Aijmer, Karin. 1984. 'Sort of' and 'Kind of' in English Conversation. Studia Linguistica 38(2): 118-128.

Andersen, Gisle. 2001. Pragmatic markers and sociolinguistic variation : A relevancetheoretic approach to the language of adolescents. Amsterdam: John Benjamins.

Andersen, Gisle. 2010. A contrastive approach to vague nouns. In: Gunther Kaltenböck, Wiltrud Mihatsch, and Stefan Schneider (eds.), New Approaches to Hedging. UK: Bingley, 35-48.

Andvik, Erik E. 1992. A pragmatic analysis of Norwegian modal particles. Dallas, Texas: The Summer Institute of Linguistics, University of Texas, Arlington.

Beeching, Kate. 2016. Pragmatic markers in British English: meaning in social interaction. Cambridge: Cambridge University Press.

Berthelin, Signe Rix, and Kaja Borthen. 2019. The semantics and pragmatics of Norwegian sentence-internal jo. Nordic Journal of Linguistics 42(1): 3-30.

Borthen, Kaja. 2014. Hva betyr 'da', da?. [What does 'da' mean?] Norsk Lingvistisk Tidsskrift 32(2): 257-306.

Brown, Penelope, and Stephen C. Levinson. 1987. Politeness : Some universals in language usage. Cambridge: Cambridge University Press.

Caffi, Claudia. 1999. On mitigation, Journal of Pragmatics 31(7): 881-9o9.

Channell, Joanna. 1994. Vague language. Oxford: Oxford University Press.

Clemen, Gudrun. 1997. The concept of hedging: Origins, approaches and definitions. In: Raija Markkanen, and Hartmut Schröder (eds.), Hedging and Discourse Approaches to the Analysis of a Pragmatic Phenomenon in Academic Texts. Berlin: Walter de Gruyter, 235-248.

Coates, Jennifer. 1987. Epistemic modality and spoken discourse. Transactions of the Philological Society 85(1): 110-131. 
Diewald, Gabriele. 2006. Discourse particles and modal particles as grammatical elements. In: Kerstin Fischer (ed.), Approaches to discourse particles. Amsterdam: Elsevier, 403-426.

Farr, Fiona, and Anne O'Keeffe. 2002. Would as a hedging device in an Irish context: An intra-varietal comparison of institutionalised spoken interaction. In: Randi Reppen, Susan M. Fitzmaurice, and Douglas Biber (eds.), Using corpora to explore linguistic variation. Amsterdam: John Benjamins, 25-48.

Fraser, Bruce. 1980. Conversational mitigation. Journal of Pragmatics 4(4): 341-350.

Fraser, Bruce. 2010. Pragmatic competence: The case of hedging. In: Gunther Kaltenböck, Wiltrud Mihatsch, and Stefan Schneider (eds.), New approaches to hedging. UK: Bingley, 15-34.

Fretheim, Thorstein. 1979. Demperen "nesten" En pragmatisk studie. [The hedge «nesten » A pragmatic study] Maal og Minne 3-4: 182-219.

Fretheim, Thorstein. 1981. "Ego"-dempere og "alter"-dempere. [«Ego »-hedges and « alter »-hedges] Maal og Minne: 86-10o.

Hagen, Kristin. (2008). Transkripsjonsveiledning for NOTA-OSLO. Oslo: Universitetet i Oslo.

Hasund, Ingrid Kristine. 2003. The discourse markers like in English and liksom in Norwegian teenage language : A corpus-based, cross-linguistic study. University of Bergen and Agder University College.

Holmes, Janet. 1982. Expressing Doubt and Certainty in English. RELC Journal 13(2): 9-28.

Hübler, Axel. 1983. Understatements and hedges in English. Amsterdam/Philadelphia: John Benjamins Publishing.

Hunston, Susan. 2002. Corpora in applied linguistics. Cambridge: Cambridge University Press.

Hyland, Ken. 1996. Writing without conviction? Hedging in science research articles. Applied Linguistics 17(4): 433-454.

Hyland, Ken. 1998. Hedging in scientific research articles. Amsterdam/Philadelphia: John Benjamins Publishing.

Johansson, Stig, and Berit Løken. 1997. Some Norwegian discourse particles and their English correspondences. In: Carl Bache, and Alex Klinge (eds.), Sounds, Structures and Senses. Essays Presented to Niels Davidsen-Nielsen on the Occasion of His Sixtieth Birthday. Odense: Odense University Press, 149-187.

Johansen, Stine. H. (2018). Exploring new approaches to the corpus-based contrastive study of hedging strategies in spoken language. Paper presented at the Using Corpora in Contrastive and Translation Studies (5th edition), Louvain-la-neuve. https://cdn.uclouvain.be/groups/cms-editors-cecl/uccts2018/UCCTS2O18_book _of_abstracts_o1.pdf. 
Johansen, Stine. H. (2019). Exploring the use of probes in a corpus pragmatic study of hedging strategies Nordic Journal of English Studies, 18(1): 121-148. doi:http://doi .org/10.3536o/njes.493.

Jucker, Andreas H., and Yael Ziv. 1998. Discourse markers: Descriptions and theory. Amsterdam: John Benjamins.

Jucker, Andreas H., Sara W. Smith, and Tanja Lüdge. 2003. Interactive aspects of vagueness in conversation. Journal of Pragmatics 35(12): 1737-1769.

Kaltenböck, Gunther, Wiltrud Mihatsch, and Stefan Schneider (eds.). 2010. New approaches to hedging. UK: Bingley.

Kranich, Svenja. 2011. To hedge or not to hedge: The use of epistemic modal expressions in popular science in English texts, English-German translations, and German original texts. Text \& Talk: An Interdisciplinary Journal of Language, Discourse \& Communication Studies 31(1): 77-99.

Lakoff, George. 1972. Hedges: A study in meaning criteria and the logic of fuzzy concepts. In: Paul M. Peranteau, Judith N. Levi, and Gloria C. Phares (eds.), Papers from the Eighth Regional Meeting of the Chicago Linguistic Society. Chicago: Chicago Linguistic Society, 183-228. [Reprint 1973 in Journal of Philosophical Logic 2(4): 458-508].

Markkanen, Raija, and Hartmut Schröder. 1997. Hedging and discourse : Approaches to the analysis of a pragmatic phenomenon in academic texts. Berlin: Walter de Gruyter.

Nikula, Tarja. 1997. Interlanguage view on hedging. In: Raija Markkanen, and Hartmut Schröder (eds.), Hedging and Discourse Approaches to the Analysis of a Pragmatic Phenomenon in Academic Texts. Berlin/New York: Walter de Gruyter, 188-207.

Overstreet, Maryann. 1999. Whales, candlelight, and stuff like that: General extenders in English discourse. Oxford: Oxford University Press.

Overstreet, Maryann. 2011. Vagueness and hedging. In: Gisle Andersen, and Karin Aijmer (eds.), Pragmatics of Society. Berlin/Boston: Mouton De Gruyter, 293-320.

Prince, Ellen, Joel Frader, and Charles Bosk. 1982. On hedging in physician-physician discourse. In: Robert J. di Pietro (ed.), Linguistics and the Professions. Norwood-New Jersey: Ablex 1-29 (paginated pre-print).

Prokofieva, Anna, and Julia Hirschberg. 2014. Hedging and Speaker Commitment.

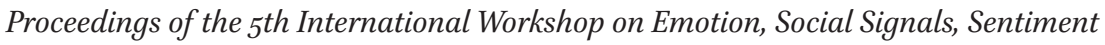
\& Linked Open Data (ES3LOD 2014). Reykjavik, Iceland, 10-13.

Romero-Trillo, Jesús. 2018. Corpus pragmatics and second language pragmatics: A mutualistic entente in theory and practice. Corpus Pragmatics: International Journal of Corpus Linguistics and Pragmatics 2(2): 113-127.

Rygg, Kristin. 2017. 'Typically Norwegian to be impolite.' Impoliteness according to whom?. FLEKS Scandinavian Journal of Intercultural Theory and Practice 4(1): 1-15.

Salager-Meyer, Françoise. 1994. Hedges and textual communicative function in medical English written discourse. English for Specific Purposes 13(2):149-170. 
Tchizmarova, Ivelina K. 2005. Hedging functions of the Bulgarian discourse marker xajde. Journal of Pragmatics 37(8): 1143-1163.

The British National Corpus 2014. User Manual and Reference Guide (2018). Lancaster University. Retrieved from http://corpora.lancs.ac.uk/bnc2014/doc/ BNC2014manual.pdf.

Vold, Eva Thue. 2006. Epistemic modality markers in research articles: A cross-linguistic and cross-disciplinary study. International Journal of Applied Linguistics 16(1): 61-87.

Weinreich, Uriel. 1966. On the semantic structure of English. In: Joseph H. Greenberg (ed.), Universals of language. Cambridge, MA: MIT Press, 142-216.

Yang, Yingli. 2013. Exploring linguistic and cultural variations in the use of hedges in English and Chinese scientific discourse. Journal of Pragmatics $50(1): 23^{-36}$.

Zadeh, Lotfi Aliasker. 1965. Fuzzy sets. Information and Control 8(3):338-353.

\section{Corpora}

"BigBrother-korpuset". In: Tekstlaboratoriet, ILN, Universitetet i Oslo. https://www .hf.uio.no/iln/english/about/organization/text-laboratory/services/index.html\# speech

Johannessen, Janne Bondi, Joel Priestley, Kristin Hagen, Tor Anders Åfarli, and Øystein Alexander Vangsnes. 20og. The Nordic Dialect Corpus - an Advanced Research Tool. in Kristiina Jokinen and Eckhard Bick (eds.), Proceedings of the 17th Nordic Conference of Computational Linguistics NODALIDA 2009. https://www.hf.uio.no/ iln/english/about/organization/text-laboratory/services/index.html\#speech

Love, Robbie, Claire Dembry, Andrew Hardie, Vaclav Brezina, and Tony McEnery. 2017. 'The Spoken BNC2014', International Journal of Corpus Linguistics, 22: 319-44. https://cqpweb.lancs.ac.uk/

"Norsk talespråkskorpus - Oslodelen". In: Tekstlaboratoriet, ILN, Universitetet i Oslo. https://www.hf.uio.no/iln/english/about/organization/text-laboratory/services/ index.html\#speech 